$\begin{array}{ll}\text { Abstracta Iranica } & \begin{array}{l}\text { Abstracta Iranica } \\ \text { Revue bibliographique pour le domaine irano-aryen }\end{array} \\ & \text { Volume } \mathbf{4 2 - 4 3} \text { | } \mathbf{2 0 2 1} \\ & \text { Comptes rendus des publications de 2019-2020 }\end{array}$

\title{
Andrei Macar. „Das ostsyrische Mönchtum in den Kanons der Synode von İšo` yahb I. aus dem Jahr $585^{\prime \prime}$
}

Christelle Jullien

\section{(2) OpenEdition Journals}

Édition électronique

URL : https://journals.openedition.org/abstractairanica/54149

DOI : 10.4000/abstractairanica. 54149

ISSN : 1961-960X

Éditeur :

CNRS (UMR 7528 Mondes iraniens et indiens), Éditions de l'IFRI

Référence électronique

Christelle Jullien, «Andrei Macar. „Das ostsyrische Mönchtum in den Kanons der Synode von Ǐšōyahb I. aus dem Jahr 585" ", Abstracta Iranica [En ligne], Volume 42-43| 2021, document 25, mis en ligne le 30 décembre 2021, consulté le 01 janvier 2023. URL : http://journals.openedition.org/ abstractairanica/54149; DOI : https://doi.org/10.4000/abstractairanica.54149

Ce document a été généré automatiquement le 1 janvier 2023.

Tous droits réservés 


\section{Andrei Macar. „Das ostsyrische Mönchtum in den Kanons der Synode von İšō yahb I. aus dem Jahr $585^{\prime \prime}$}

Christelle Jullien 


\section{RÉFÉRENCE}

Andrei Macar. „Das ostsyrische Mönchtum in den Kanons der Synode von İ̌̌o`‘ yahb I. aus dem Jahr 585" in Sh. Talay (ed.). Überleben im Schatten: Geschichte und Kultur des syrischen Christentums. Beiträge des 10. Deutschen Syrologentages an der FU Berlin 2018. Wiesbaden: Harrassowitz Verlag, 2020, p. 133-146, ISBN 9783447114639, (Göttinger Orientforschungen I. Reihe: Syriaca 58).

1 S'appuyant sur l'enquête terminologique distinguant dayro (couvent associé à une école) de 'umro (monastère) proposée en 2008 par F. Jullien à partir d'une étude centrée sur le Livre des fondateurs d'Ī̌̌ō'denah de Bașra (Le monachisme en Perse, p. 100-101), l'A. effectue un relevé des termes monastiques utilisés dans les canons 8-12 du synode $\mathrm{d}^{\prime} \mathrm{I}^{\mathrm{s}} \overline{0}^{\mathrm{c}} \mathrm{yahb} \mathrm{I}^{\mathrm{er}}$ (582-595) pour désigner les structures monastiques; il constate un usage globalement synonymique (p. 135-137), ce qui pourrait permettre de nuancer l'hypothèse initiale. Toutefois, comme le rappelle d'ailleurs l'A., pareille distinction lexicographique et structurelle semble être devenue caduque dans les sources postérieures au $\mathrm{VIII}^{\mathrm{e}}$ siècle. On sait d'ailleurs que la collection des synodes fut précisément compilée au IX ${ }^{e}$ siècle sous le patriarche Timothée I $^{\text {er }}$ (780/99-823). Il reste qu'une analyse sur un corpus plus vaste serait nécessaire avant d'en tirer des conclusions intéressantes, en tenant compte aussi des évolutions et des époques d'écriture, notamment pour les synodes orientaux ; la notion même de cellule, qlyt', requerrait pareil examen.

\section{AUTEURS}

CHRISTELLE JULLIEN

CNRS, CeRMI, Paris 